\title{
Impact of technical diagnostics interval on machinery maintenance
}

Ing. Karel Mayer, Ing. Martin Pexa, Ph.D., Ing. Jindřich Pavlů

Faculty of Engineering, Czech University of Life Sciences Prague, Kamýcká 129, 16521 Praha 6 - Suchdol, Czech Republic. E-mail: pexa@tf.czu.cz

\begin{abstract}
Machinery maintenance significantly participates in its reliable, serviceable and safe operation. Well-timed maintenance can identify a fault condition of machinery leading to manufacturing a product of poor quality. Maintenance interval can be fixed or maintenance can be done when needed, meaning at the moment when some of operating parameters get worse. An example of determination of diagnostics interval set based on machinery vibrodiagnostic measurement is described in the paper. The shown steps are universal and can be applied to another technical diagnostics methods as for example tribodiagnostics, thermodiagnostics, non-destructive materiology etc.. This way economic savings can be reached better comparing to maintenance done in fixed planned dates.
\end{abstract}

Keywords: maintenance, diagnostics interval, vibrodiagnostics.

\section{Acknowledgement}

In relation to writing this paper we need to thank our colleagues-diagnosticians above all, for their pro-active approach in implementation of new methods of diagnostics management.

This paper was created with a grant support of project $\check{C} Z U$ U1190/1312/3122 (Czech University Of Agriculture in Prague) - "Impact of biofuels and operation parameters on engine smoke"

\section{References}

[1] ALEŠ, Z., PEXA, M., (2010). Diagnostika maziv s využitím laserového analyzátoru LASERNET FINES®-C, in: Strojírenská technologie, Ročník XIV, zvláštní vydání, Univerzita Jana Evangelisty Purkyně, FVTM, Ústí nad labem, 2010, s. 8-11. ISSN 1211-4162

[2] JUZENAS, E., JONUŠAS, R., JUZENAS, K., (2008). Defects diagnostics of rolling bearings of low speed machines, VIBROENGINEERING 2008, in: Proceedings of 7th International Conference 2008, s. 59-62.

[3] LI G, HUANG P, CHEN P, HOU D, ZHANG G, ZHOU Z. (2010). Quantitative nondestructive estimation of deep defects in conductive structures. In: International Journal of Applied Electromagnetics and Mechanics, Ročník 33, Číslo 3-4, 2010, s. 1273-1278. ISSN 1383-5416

[4] POŠTA, J. (2006). Provozuschopnost strojů. Česká zemědělská univerzita v Praze, 2. vydání, Praha, 2006. ISBN 80-213-0966-0

[5] SAVIC, B. M., JOVANOVIC, V. (2009). Determining the optima interval for the technical diagnostics of bearings. Proceedings - ASME international manufacturing science and engineering conference, s. 41-46, 2009. ISBN 978-0-7918-4362-8

[6] SHAH AA, RIBAKOV Y. (2009). Non-destructive evaluation of concrete in damaged and undamaged states. In: Materials and Design. 2009; Ročník 30, číslo 9, 2009, pp. 3504-3511. ISSN: 0261-3069

[7] STODOLA J, STODOLA P. (2010). Mechanical system wear and degradation process modelling. In: Transactions of Famena. Ročník 34, číslo 4, 2010, s19-32. ISSN: 1333-1124

[8] ŽIŽKA, J., LINHART, T. (2009). Určování stavu opotřebení soustružnického nože pomocí poměru složek řezné síly, in: Strojírenská technologie, Ročník XIV, číslo 1, Univerzita Jana Evangelisty Purkyně, FVTM, Ústí nad labem, 2010, s. 23-28. ISSN 1211-4162

[9] ČSN EN 571-1 01 5017. Nedestruktivní zkoušení - Kapilární zkouška - Část 1: Obecné zásady. Praha: Český normalizační institut, 1998.

[10] ČSN EN ISO 3452-2 01 5018. Nedestruktivní zkoušení - Zkoušení kapilární metodou - Část 2: Zkoušení kapilárních prostředků. Praha: Český normalizační institut, 2007.

[11] ČSN EN ISO 3452-3 01 5018. Nedestruktivní zkoušení - Kapilární zkouška - Č́st 3: Kontrolní měrky. Praha: Český normalizační institut, 1999.

[12] ČSN EN ISO 3452-4 01 5019. Nedestruktivní zkoušení - Kapilární zkouška - Část 4: Vybavení. Praha: Český normalizační institut, 1999. 
[13] ČSN EN 47301 5004. Nedestruktivní zkoušení - Kvalifikace a certifikace pracovníků NDT - Všeobecné zásady. Praha: Úřad pro technickou normalizaci, metrologii a státní zkušebnictví, 2009.

[14] ČSN EN 128905 1176. Nedestruktivní zkoušení svarů - Zkoušení svarů kapilární metodou - Stupně přípustnosti. Praha: Český normalizační institut, 1999.

[15] ČSN EN ISO 9934-1. Nedestruktivní zkoušení - Zkoušení magnetickou metodou práškovou - Část 1: Všeobecné zásady. Praha: Český normalizační úřad, 2002.

[16] ČSN EN ISO 9934-2. Nedestruktivní zkoušení - Zkoušení magnetickou metodou práškovou - Část 2: Zkušební prostř̌edky. Praha: Český normalizační úřad, 2003.

[17] ČSN EN ISO 9934-3. Nedestruktivní zkoušení - Zkoušení magnetickou metodou práškovou - Č́st 3: Přístroje. Praha: Český normalizační úřad, 2003.

[18] ČSN EN ISO 3059. Nedestruktivní zkoušení - Zkoušení kapilární a magnetickou práškovou metodou - Podmínky prohlížení. Praha: Český normalizační úřad, 2002.

[19] ČSN EN 1290. Nedestruktivní zkoušení svarů - Zkoušení svarů magnetickou metodou práškovou. Praha: Český normalizační úřad, 2000.

[20] ČSN EN 1291. Zkoušení svarů magnetickou metodou práškovou - Stupně př́pustnosti. Praha: Český normalizační úr̆ad, 2000.

[21] ČSN EN 1714. Nedestruktivní zkoušení svarů - Zkoušení svarových spojů ultrazvukem. Praha: Český normalizační úr̆ad, 1999.

[22] ČSN EN 1712. Nedestruktivní zkoušení svarů - Zkoušení svarových spojů ultrazvukem - Stupně př́ipustnosti. Praha: Český normalizační úřad, 1999.

[23] ČSN EN ISO 23279. Nedestruktivní zkoušení svarů - Zkoušení ultrazvukem - Posouzení charakteru indikací ve svarech. Praha: Český normalizační úřad, 2010.

Paper number: M201210

Manuscript of the paper recieved in 2011-11-21. The reviewers of this paper: Prof. Jan Skalla, MSc., Ph.D. and Dr. Milan Dian, MSc. 